\title{
IDEOLOGI KAPITALISME DALAM SAMPUL FIKSI ISLAMI INDONESIA
}

\author{
Citra Nuraini
}

\begin{abstract}
Abstrak. Penelitian ini bertujuan untuk mengetahui ideologi kapitalisme dalam sampul fiksi popular Islam Indonesia. Ideologi kapitalisme dianalisis berdasarkan tiga kriteria: selera pasar, penitraan, dan popularitas. Penelitian ini tidak terkait pada tempat tertentu. Penelitian ini dilakukan dari bulan Januari 2014 sampai dengan Juni 2014. Metode yang digunakan adalah deskriptif kualitatif dengan teknik analisis isi. Teknik analisis isi dilakukan dalam dua tahap. Pertama, menganalisis sampul-sampul fiksi dari tahun 20002013 secara kuantitatif untuk mengetahui pola-pola umum perkembangan sampul fiksi beserta elemen-elemen sampul yang muncul dalam rentang waktu tersebut. Kedua, menganalisis sampul fiksi berdasarkan elemen-elemen yang ditemukan tersebut dengan pendekatan semiotika dan ideologi. Penelitian ini berfokus melihat bagaimana sampul berperan dalam kapitalisme industri penerbitan. Subfokus penelitian melihat bagaimana mitos-mitos digunakan untuk mengkonstruk sampul fiksi. Hasil penelitian memperlihatkan bahwa sampul berperan sebagai iklan dalam fiksi islam indonesia. Penelitian ini merupakan penelitian pendahuluan, diharapkan ada penelitian lanjutan.
\end{abstract}

Kata kunci: ideologi, kapitalisme, sampul fiksi, fiksi islam, mitos

\section{PENDAHULUAN}

Jatuhnya rezim otoriter Soeharto memunculkan dinamika sosial baru yang ditandai dengan kebebasan berekspresi. Termasuk dalam dunia sastra. Fenomena kebebasan ekspresi dalam dunia sastra, salah satunya adalah kemunculan fiksi-fiksi berlabel Islami.

Kemunculan genre fiksi ini pada awalnya digagas dan dimotori oleh Helvy Tiana Rosa (kemudian bersama Asma Nadia dan kawan-kawan) melalui Forum Lingkar Pena (FLP) yang pernah dirintis dan diasuhnya. FLP merupakan komunitas calon penulis yang didirikan pada 22 Februari 1997. Komunitas ini melahirkan sejumlah penulis beserta karyanya yang menonjolkan unsur dakwah agama (baca: Islam) (Suryanata, 2012).

Kemunculan FLP tidak terlepas dari peran Majalah Annida. Sebelum mendirikan FLP, Helvy Tiana Rosa telah menjadi Redaktur Pelaksana di Majalah Annida dari tahun 1991-1997. Tahun 1997 Helvy diangkat menjadi Pemimpin Redaksi dan pada tahun 2001 mengundurkan diri. Majalah fiksi Islami bertiras seratus ribu eksemplar perbulan ini dimanfaatkan sebagai sarana memunculkan karya-karya FLP. Banyak penulis FLP yang mengasah kemampuan menulisnya dengan mengirimkan karyanya ke Annida. Dan bahkan selama 10 tahun keterlibatan Helvy di Annida, majalah fiksi remaja Islami itu menjadi media komunikasi yang efektif bagi Forum Lingkar Pena (FLP). Hampir seluruh anggota FLP adalah pembaca dan penulis majalah Annida yang mendaftar menjadi anggota melalui majalah tersebut.

Beberapa karya yang telah diterbitkan majalah Annida maupun yang tidak melalui majalah Anndia, kemudian dibukukan melalui penerbit Islam yang sejak awal menerbitkan buku-buku Islami, seperti Asy Syamil, Mizan, Gema Insani Press, dan FBA. Di sinilah dimulai pelabelan fiksi Islami. Misalnya Mizan, membentuk divisi yangkhusus menerbitkan fiksi Islami bernama Divisi Buku Anak dan Remaja Mizan 
(DAR!Mizan).Tidak berlebihan jika ada yang mengatakan industri perbukuan Indonesiaberhutang besar kepada (pengarang-pengarang) FLP (Irkham, 2012: 335-342).

Kemunculan fiksi Islami di Indonesia pascareformasi ini menimbulkan sejumlah perdebatan. Muhammad Ali, sastrawan kelahiran Surabaya, dalam esainya 'Masalah Sastra Islam' yang terkumpul dalam buku Ihwal Dunia Sastra: Kumpulan Esai mengatakan label "sastra Islam" itu sungguh penuh kekaburan. Penyebutan sastra Islam berbeda dengan penyebutan sastra Barat, sastra Timur, sastra Arab, sastra Amerika, atau sastra Indonesia. Karena yang disebut-sebut itu jelas definisinya, bahasanya, kecenderungan etnologi, dan paling gampang bisa terdefinisi batasan geografisnya (Ali, 1986: 53-57). Sedangkan Muhidin M. Dahlan menyebutkan bahwa sisi positif dari pelabelan ini adalah adanya ikatan emosi antarkomunitas Islam karena mampu memberi penanda identitas yang jelas dan tuntas. Di sisi yang lain, ada kesadaran bahwa ini adalah bagian dari gerakan dakwah. Sedang sisi negatifnya, pelabelan ini dapat berpotensi meminggirkan karya-karya lain yang mengangkat isu kemanusiaan, keadilan, dan semacamnya (yang merupakan elemen substantif agama), sebagai karya yang bukan sastra bernapaskan Islam (Dahlan, 2008).

Label fiksi Islami ini sebenarnya tidak menimbulkan kekaburan karena bukan berdasarkan isi, tapi merek. Hal inilah yang ditegaskan oleh kurniasih dalam melihat fenomena fiksi Islami. Kurniasih melihat ini dari kategorisasi sastra tinggi dan sastra rendah. Booming fiksi Islami sekarang ini hanya sebagai bagian dari kapitalisasi karena berhubungan dengan sastra populer. Sesungguhnya fiksi Islami sejak dulu sudah ada tapi tidak mengatasnamakan label Islam. Oleh karena itu, Kemunculan fiksi Islami saat ini tidak lebih sebagai bagian dari budaya massa. Masyarakat massa terbentuk melalui kekuatan teknologi (mekanisasi, industrialisasi), organisasi ekonomi (pabrik, pasar, advertensi), diferensiasi sosial (kelas, suku, agama), mobilisasi politik (negara, partai), dan budaya (sport, musik pop, pendidikan, media massa).

Budaya massa ini pun merambah sampai ke dunia sastra Islam. yang akhirnya menjadi merek dagang, dimana nilai yang ditujunya adalah konsumen semata. ${ }^{8}$ Hal terpenting yang dibela di sini adalah sejauh mana karya-karya itu mampu membuka mata pembaca. Seberapa dalam nilai-nilai Islam yang ditawarkan di dalamnya. Kalau yang diutamakan adalah sebanyak-banyaknya pembaca yang hendak diraih, itu memang khas industri penerbit sebagai bagian budaya massa (Kurniasih, 2008).Artinya, fiksi Islami menjadi brand image bagi konsumen. Argumen Kurniasih ini ditanggapi Topik Mulyana, pegiat FLP Bandung dan editor Penerbit Syaamil Cipta Media. Dia menegaskan bahwa FLP sengaja menggunakan budaya massa tersebut sebagai kendaraan operasionalnya. Tujuan utamanya penyebaran nilai dakwah agama (Islam). Dia mengatakan bahwa FLP punya tujuan menciptakan masyarakat yang gemar membaca dan menulis (Mulyana, 2007).

Dalam mencapai visinya memasyarakatkan gemar membaca dan menulis, FLP berfokus melahirkan penulis-penulis baru. Sebab, selama ini komunitas sastra yang hanya dari kalangan yang telah menjadi sastrawan atau mereka yang digolongkan sastrawan elite tersebut. Hampir semua anggota FLP pada awalnya hanyalah calon penulis, bukan penulis/sastrawan yang sudah jadi. Para anggota FLP juga tidak tumbuh bersama sejumlah nama besar yang menempel di belakangnya (Rosa, 2007). Oleh karena itu, FLP lebih banyak menghasilkan sastra populer yang mudah dipahami masyarakat. FLP ingin melawan sastra serius atau elit yang hanya berkutat pada seni tinggi yang sering kali tidak dipahami masyarakat (Mulyana, 2007).

Hal ini menunjukan bahwa sesungguhnya FLP ingin melakukan konter hegemoni pada beberapa kecenderungan kesusastraan melalui sastra populer. Wujud fiksi Islami pasca reformasi sebagai sastra popular ini dipertegas dengan peran media massa dan 
labelisasi dari penerbit. Sastra popular ini merupakan bagian dari budaya massa. Sapardi Djoko Damono, menegaskan sastra kita adalah sastra media massa, perkembangannya lebih jelas lewat koran atau majalah tinimbang lewat buku. Sapardi mengatakan bahwa jika media massa sudah bersandar pada cita rasa khalayak, maka sastra yang dimuatnya pun sebenarnya berorientasi citra rasa khalayak pula. Jika penyebaran seluas-luasnya isu menjadi syarat utama, maka salah satu ciri budaya populer dengan sendirinya terpenuhi (Damono, 1984: 20).

Dalam sejarahnya budaya populer lahir karena sistem kapitalisme yang semakin kokoh pasca revolusi industri. Sebab dengan revolusi industri, berkembanglah industrialisasi di segala bidang, termasuk industri penerbitan. Perkembangan industrialisasi berperan besar dalam memberikan ruang bagi tumbuhnya 'sastra massa' atau 'sastra populer', yaitu bentuk-bentuk sastra yang mempunyai akar pada kebutuhan, cara berpikir, pengetahuan, problematika dan selera orang-orang kebanyakan. Sastra macam ini menjadi bagian dari 'industri budaya' (culture industry), yang diproduksi untuk massa yang luas melalui pola-pola industrial. Ada semacam proses 'kapitalisasi', di mana sastra-dengan sengaja atau tak disengaja - menjadi tempat untuk mendapatkan keuntungan ekonomi, di dalam sebuah komodifikasi budaya.

Setiap penerbitan sastra populer, termasuk didalamnya fiksi Islami, menargetkan penjualan best seller. Best seller adalah sebuah perpektif bisnis yang ditempatkan dalam wilayah produksi sastra. Konsep ini lahir ketika produksi buku (sastra) mengalami perubahan signifikan, yakni ketahap industrilisasi. Sementara jumlah penikmat buku meningkat secara massif (Bloom, 2008: 28).

Ahmadun Yosi Heryanda dalam makalah Kongres Bahasa Indonesia 2013 mengutarakan bahwa ketika produksi sastra ditempatkan dalam perspektif bisnis, sesungguhnya ketika itu pula karya sastra telah mengalami pergeseran fungsi, tidak hanya sebagai produk kultural tetapi juga produk industri. Karena itu, sebagaimana lazimnya sebuah sistem industri, karya sastra akan dianggap sebagai 'komoditas' yang menjadi salah satu alat perputaran modal. Karya sastra masuk dalam proses industrilisasi yang hampir sepenuhnya bergerak untuk kepentingan pasar. Ketika tarikan pasar terhadap novel pop begitu kuat, maka penerbitan novel pop mengalami kapitalisasi yang begitu besar. Hal ini telah terjadi pada baik pop sekuler maupun pop Islam (Herfanda, 2013).

Di sini pula selera konsumen - seperti yang dipahami oleh industriawan --sering sangat menentukan corak komoditas tersebut. Meskipun, 'selera konsumen' itu sering bersifat semu. Artinya, seringkali hanya berdasarkan praduga pebisnis. Mirip dengan rating acara televisi, maka tarikan pasar buku-buku sastra tertentu menjadi indikasi utama untuk menengarai selera konsumen.

Best seller dapat dicapai jika ideologi sastra populer semakin dekat denganideologi pembaca. Untuk itu diperlukan iklan. Salah satu bentuk iklan dalam dunia penerbitan buku ialah sampul buku.dalam dunia penerbitan, sampul atau sarung adalah bagian dari sarana promosi. Karena itu, rancangan sampul harus mampu menarik perhatian pembaca (Mansor, 1993). Sehingga desain sampul buku mengandung nilai-nilai yang menghubungkan penerbit dengan pembaca.

Menurut FX. Widyatmoko, disarikan dari buku Merupa Buku, penciptaan desain sampul buku tidak terlepas dari nilai-nilai yang menopangnya. Hal ini karena desain tidak terlepas dari ruang budaya yang membentuknya. Desain ada dan tercipta selalu dalam ruang budaya. Menurutnya, seorang desainer, sebagai aktor kreatif, mencipta dan dipengaruhi nilai-nilai dalam sikap dan pandangan hidup. Disisi lain, penulis, pembaca, dan penerbit juga berada dalam aturan nilai-nilai budaya pada kurun waktu tertentu. Kaitan 
antar pihak tersebut membentuk karakter gaya ilustrasi sebuah desain pada tiap-tiap zaman. Dan dibalik gaya tersebut terdapat nilai-nilai yang menopangnya (Koskow, 2009).

Menurutnya, ideologi atau nilai-nilai termanisfestasikan secara fisik dalam pemilihan gaya desain sampul buku. Sampul buku merupakan ruang berbagai kepentingan karena sampul buku merupakan pintu awal konsumen mengenal buku. Sehingga sampul buku merupakan tempat yang tepat bagi produsen untuk melancarkan komunikasi persuasif demi mendongkrak penjualan.

Iklan pun merupakan sebuah teks yang berwacana. Teks sastra sebagai praktik sosial terjadi berkat dan dalam ideologi. Artinya, ideologi diartikan sebagai cara apa yang kami katakan dan percayai terhubung dengan struktur kekuasaan dan hubungan kekuatan masyarakat kita tinggal (Eagliton, 2006: 14).Periklanan dalam proses produksi sastra populer bertujuan untuk mendekatkan produksi massa dengan konsumsi massa. Kathy Myers menjelaskan bahwa iklan secara signifikan memiliki peran sentral dalam perencanaan ekonomi, sebagai mediator produksi dan konsumsi. Dia mengutip pendapat Brewset dan Palmer dalam Introductionof Advertising, "periklanan adalah penjualan massa, tanpa periklanan produksi massatidak akan dapat berfungsi (Myers, 2012)."Fungsi iklan dalam budaya populer ditegaskan oleh Micael Danesi dalamUnderstanding Media Semiotik. Dunia kontemporer dipengaruhi oleh interaksi dinamisantara periklanan, tren budaya pop, dan kecenderungan umum sosial yang saling besinergi. Posisi iklan dalam budaya populer saat ini iklan telah berfungsi sebagai alat komunikasi massa dan alat membujuk (Danesi, 2002: 174).

Menurut Gramsci, tugas iklan adalah menciptakan 'identitas' bagi suatu produk ditengah citra yang saling bersaing dengan mengasosiasikan merek tersebut dengan nilainilai manusiawi yang dikehendaki. Membeli suatu merek, bukan hanya soal membeli barang tetapi juga soal membeli gaya hidup dan nilai (Barker, 2011:64). Maka dari itu, penelitian mengenai peran iklan dalam proses produksi budaya populer sangat penting.

Penelitian tentang peran iklan dalam kebudayaan populer sebetulnya telah banyak dilakukan oleh para peneliti. Namun, penelitian dalam wilayah sastra jarang ditemukan. Penelitian sastra tidak banyak menyentuh tataran produksi sastra, utamanya terkait menghubungan teks dengan penerbitan sebagai lembaga bisnis. Sehingga, penelitian ini merupakan penelitian baru. Oleh karena itu, penelitian ini akan berfokus pada permainan sampul buku sebagai iklan dalam fiksi populer Islam Indonesia.

\section{METODE PENELITIAN}

Penelitian ini menggunakan metode kualitatif deskriptif dengan bantuan teknik analisis isi kualitatif dan teknik semiotik serta ditopang dengan teori ideologi. Metode deskriptif kualitatif ialah mendeskripsikan data berdasarkan temuan, sedangkan teknik analisis isi kuantitatif adalah analisis yang dipakai untuk mengukur aspek-aspek tertentu dari data yang dilakukan secara kuantitatif. Analisis isi kuantitatif hanya memfokuskan ada bahan yang tersurat saja. Peneliti hanya men-coding (memberi tanda ada bahan yang tersurat tersebut).

Objek pada penelitian ini berupa sampul-sampul buku fiksi Islam Indonesia dari tahun 2000 hingga tahun 2013. Sampul didapat dari data yang tersedia di beberapa penerbit, yakni Republika, Gema Insani, Pustaka Al-Kautsar, Noura Books, dan Zikrul hakim.

\section{HASIL DAN PEMBAHASAN}

Berdasarkan analisis data dapat menunjukan bahwa sampul berfungsi sebagai sebagai iklan. Didalam sampul terdapat mekanisme membujuk. Hal ini didalam sampul 
bekerja ideologi kapitalisme. Bentuk-bentuk ideologi kapitalisme dalam sampul antara lain: ketertundukan pada selera pasar, menciptakan pencitraan, dan dominasi nilai popularitas.

Ideologi kapitalisme selalu memproduksi produk berstandar selera pasar, termasuk penerbitan fiksi populer. Dalam konteks sampul fiksi, di dalam menggambarkan unsurunsur yang disukai massa. Dalam sampul ini unsur selera pasar ialah asmara dan nilai-nilai patriarki. Mitos asmara ini terdapat di penggunaan slogan dan gambar ilustrasi. Sementara, mitos patriarki ditemukan dalam gambar ilustrasi berunsur seksualitas dan domestik.

Ideologi kapitalisme pun mengandalkan sebuah pencitraan. Pencitraan dibangun untuk menciptakan kesadaran baru dibenak konsumen agar mau membeli produk yang ditawarkan. Pencitraan akan menyentuh gaya hidup konsumen. Konsumen membeli produk bukan hanya untuk mendapatkan kegunaan produk, melainkan juga untuk mendapatkan citra produk. Pada sampul fiksi Islami indonesia dibangun dengan pencitraan religiusitas, pencitraan motivasi, pencitraan kualitas. Pada sampul fiksi Islami paling banyak menggunakan citra religiusitas.

Mitos religiusitas membentuk sebuah citra 'karya Islami'. Citra religiusitas dibutuhkan untuk mempertegas bahwa karya fiksi Islami memiliki nilai-nilai religiusitas. Citra religiusitas ditempelkan di sejumlah elemen sampul, seperti endorsment, slogan, label, dan gambar ilustrasi. Strategi pencitraan religiusitas di endorsment dibentuk dengan menampilkan komentar-komentar yang mengarah pada nilai religiusitas karya. Selain itu, latar belakang endorser juga membantu mempertegas citra religiusitas karya. Hal ini terlihat dari strategi-strategi periklanan sampul yang banyak menunjukkan mitos religiusitas.

Citra 'motivasi' merupakan salah satu bentuk pencitraan yang terdapat dalam fiksi islami. Beberapa fiksi islam ini dicitrakan sebagai fiksi yang dapat memotivasi manusia. Dalam konteks karya fiksi, dengan menempelkan mitos motivasi pada karya, penerbit bermaksud untuk mencitrakan bahwa fiksi tersebut mengandung nilai 'motivasi' bagi para pembaca. Sehingga pembaca tidak hanya membeli karya fiksi tersebut, tetapi juga nilainilai motivasi yang dicitrakan oleh sampul. Mitos motivasi paling banyak muncul di dalam strategi periklanan dengan penggunaan slogan. Strategi periklanan dengan menampilkan slogan 'motivasi ini' bermunculan pasca terbitnya Ayat-Ayat Cinta.

Mitos kualitas membentuk citra sebuah karya berkualitas. citra'kualitas' ini dibutuhkan mengingat fiksi populer seringkali dianggap memiliki kualitas sastra yang lebih rendah dibandingkan fiksi serius. Hal ini penting karena penerbit ingin menyakinkan khalayak bahwa fiksi populer pun berkualitas. Ini untuk menarik masyarakat untuk mau membeli.

Nilai-nilai popularitas lebih banyak dicapai oleh para bintang atau selebriti. Sebab, mereka adalah aktor yang telah menguasai media massa. Media massa akan menjadikan mereka komoditas yang akan dipertontokan. Dalam sampul fiksi Islami, nilai-nilai popularitas terlihat dari nilai popularitas bintang (penulis) dan penjualan massa.

Karena karyanya dikenal publik, penulis juga seorang bintang atau selebriti di bidang kepenulisan. Dalam sampul fiksi, mitos bintang ini diperlihatkan di identitas penulis dan foto penulis. Identitas penulis mengelaborasi latar belakang penulis, seperti latar prestasi, pendidikan, karya. Latar prestasi, pendidikan, karya turut menjadikan penulis populer. Citra ini yang dimanfaatkan penerbit sebagai suatu komoditas yang dijual. Minimal, citra ini akan mendongkrak penjualan karyanya.

Berdasarkan data, antara 2000-2005 popularitas penulis berusaha dibangun atas dasar hubungan dengan lembaga pengayom. Pada sampul belakang, secara khusus sampul memperlihatkan keterlibatan penulis dengan lembaga pengayom FLP. Semantara, pasca 
demam Ayat-ayat Cinta. Informasi latar belakang penulis ditempatkan di sampul depan mengikuti pola desain sampul Ayat-ayat Cinta. Bukan itu saja, pada beberapa karya informasi penulis menitikberatkan pada latar pendidikan di Al-Azhar. Paradigma yang sama juga berlaku bagi penggunaan foto penulis. Namun, umumnya strategi periklanan dengan menempelkan foto penulis hanya terjadi pada karya seorang penulis yang sudah terkenal. Mitos popularitas secara jelas terlihat dari penggunaan label best seller. Konsep best seller di Indonesia merujuk pada popularitas. Bahkan, untuk menyebut novel yangsangat popular seperti Ayat-ayat Cinta, penerbit menempelkan label mega best seller.

\section{KESIMPULAN}

Berdasarkan hasil analisis, didapatkan kesimpulan bahwa sampul fiksi Islami Indonesia berperan sebagai iklan. Perkembangan sampul fiksi populer islam indonesia menujukan penggunaan desain yang semakin rumit dengan berbagai elemen. Kerumitan desain itu menunjukan bahwa sampul fiksi semakin digunakan sebagai iklan.

Iklan merupakan bagaian dari industri-kapitalisme sehingga didalam sampul berbagai strategi periklanan digunakan sebagai bagian dari industri-kapitalisme. Strategistrategi periklanan yang ditemukan antara lain: penggunaan endorsement, penggunaan identitas penulis, penggunaan slogan, penggunaan label, penggunaan gambar ilustrasi, penggunaan foto penulis. Dalam strategi-strategi periklanan tersebut terdapat mitos-mitos yang berhubungan dengan ideologi kapitalisme. Mitos-mitos yang ditempelkan dalam sampul, antara lain: mitos religiusitas, mitos motivasi, mitos asmara, mitos penjualan massa, mitos bintang (selebriti).

Mitos religiusitas terdapat dalam penggunaan endorsement, penggunaan label, penggunaan slogan, penggunaan gambar ilustrasi. Mitos motivasi terdapat dalam penggunaan slogan. Mitos kualitas terdapat dalam penggunaan endorsement dan penggunaan slogan. Mitos asmara terdapat dalam penggunaan slogan dan gambar ilustrasi. Mitos patriarki terdapat dalam penggunaan gambar ilustrasi, mitos bintang (selebriti) terdapat dalam penggunaan endorsement, penggunaan identitas penulis, dan foto penulis. Mitos penjualan masa terdapat dalam penggunaan label. Mitos-mitos ini terkait erat dengan ideologi kapitalisme. Ideologi kapitalime terlihat dalam sampul melalui tiga hal, yaitu: selera pasar, pencitraan, popularitas. Ketiga hal ini, digambarkan melalui mitosmitos tersebut.

Aspek selera pasar terlihat dari mitos asmara dan mitos patriarki. Mitos asmara menujukan bahwa sampul mempertagas posisi karya yang meuncul sebagai fiksi romatis. Fiksi romantis merupakan jenis atau tema fiksi yang digemari massa. Smitos patriarki munjukan bahwa dalam sampul fiksi populer islam tidak terlepas dari nilai-nilai patriarki. Nilai-nilai digunakan karena pasar mempunyai selera yang cenderung patriarki. Aspek pencitraan terlihat dari mitos religiusitas, mitos motivasi, mitos, kualitas. Inilah citra-citra digunakan untuk membujuk konsumen membeli karya (produk). Konsumen bukan hanya membeli produk tapi juga citra. Aspek popularitas terlihat dari mitos bintang (selebriti) dan mitos penjualan massa. Mitos bintang menujukan bahwa popularitas karya dibangun dengan memperlakukan penulis sebagai sebuah bintang. Mitos penjualan massa menunjukan bahwa popularitas karya terlihat karena adanya penjualan masa.

\section{DAFTAR RUJUKAN}

Ali, Muhammad Ali. 1986. Ihwal Dunia Sastra: Kumpulan Esai. Surabaya: Bina Ilmu. Barker, Chris. 2011. Cultural Studies; Teori dan Praktik. Yogyakarta: Kreasi Wacana. 
Arkhais, Vol. 06 No. 1 Januari-Juni 2015

Bloom, Clive. 2008. Bestsellers: Popular Fiction Since 1900. New York: Palgrave Macmillan.

Dahlan, Muhidin M. "Mengapa 'Kita' Menolak Sastra (Berlabel) Islam” dalam Suplemen Ruang Baca Koran Tempo, 28 April 2008.

Damono, Sapardi Djoko. 1984. Pengantar Sosiologi Sastra. Jakarta: Pusat Pembinaan dan Pengembangan Bahasa.

Danesi, Marcel. 2002. Understanding Media Semiotic. USA: Oxford University Press.

Eagliton, Terry Eagliton. 2006. Teori Sastra: Sebuah Pengantar Komperhensif. Yogyakarta: Jalasutra.

Fenomena Sastra Islami: Antara Pro dan Kontra' dalam Majalah Mahasiswa Hayamwuruk Universitas Diponegoro edisi No.1/Th. XVIII/2008.

Herfanda, Ahmadun Yosi. 2013. 'Sastra dalam Era Industri Kreatif', makalah dalam Kongres Bahasa Indonesia 2013.

Irkham, Agus M. 2012. 'Heboh Sastra Islami dalam Perspektif Komunitas Literasi dan Industri Perbukuan' dalam Gempa Literasi: dari kampung untuk Nusantara. Jakarta: Kompas Gramedia Group.

Kurniasih, "FLP dan Pendidikan Sastra" dalam Khazanah Pikiran Rakyat, Sabtu, 26 Januari 2008.

Koskow. 2009. Merupa Buku. Yogyakarta: Lkis.

Mansor, Sofia. 1993. Pengantar Penerbitan. Bandung: Penerbit ITB.

Mulyana, Taufik. "Sastra: FLP, Sastra Islam, dan Seni Tinggi" dalam Khazanah PikiranRakyat, Sabtu, 15 Desember 2007

Myers, Kathy. 2012. Membongkar Sensasi dan Godaan Iklan. Yogyakarta: Jalasutra.

Suryatana, Jamal T., sastrawan Jawa Timur, dalam eseinya Sastra Indonesia Mutakhir: Jejak Historis dan Kecenderungan Estetiknya di majalah Horison bulan Januari 2012. 
Arkhais, Vol. 06 No. 1 Januari-Juni 2015 